\title{
Role of Economic Growth, Financial Development, Trade, Energy and FDI in Environmental Kuznets Curve for Lithuania: Evidence from ARDL Bounds Testing Approach
}

\author{
Habib-ur-Rahman ${ }^{1}$, Ahmad Ghazali ${ }^{2}$, Ghulam Ali Bhatti ${ }^{3}$, Safdar Ullah Khan ${ }^{4}$ \\ ${ }^{1,4}$ Bond Business School \\ Bond University, Gold Coast, QLD 4229, Australia \\ E-mail. ${ }^{1}$ hrahman@bond.edu.au; ${ }^{4}$ skhan@bond.edu.au \\ ${ }^{2}$ Department of Commerce \\ University of Gujrat, Hafiz Hayat Campus, Gujrat, Pakistan \\ E-mail.ahmad.ghazali@uog.edu.pk \\ ${ }^{3}$ Noon Business School \\ University of Sargodha, University Road, Sargodha Punjab 40100, Pakistan \\ E-mail.ghulam.ali@uos.edu.pk \\ cross $^{\text {ref }} \underline{\mathrm{http}: / / \mathrm{dx} \text {.doi.org/10.5755/j01.ee.31.1.22087 }}$
}

\begin{abstract}
This paper examines the long-run relationship between carbon dioxide $\left(\mathrm{CO}_{2}\right)$ emission and economic growth, financial development, trade, energy consumption, and foreign direct investment in the case of Lithuania by employing time series data of 1989-2018. In particular, this paper aims to test whether the Environmental Kuznets Curve (EKC) relationship for economic growth and financial development holds or not. The autoregressive distributed lag (ARDL) bounds testing procedure is employed for the empirical analysis. The results validate the existence of EKC in the long-run as well as in the short-run since there is an inverted $U$-shaped relation between $\mathrm{CO}_{2}$ emissions and economic growth. Conversely, we could not validate the EKC relationship between $\mathrm{CO}_{2}$ emissions and financial development. Trade and energy consumption are other significant determinants of $\mathrm{CO}_{2}$ emissions. The causality analysis results show that unidirectional causality runs from economic growth to $\mathrm{CO}_{2}$ emissions and trade to $\mathrm{CO}_{2}$ emissions. The validity of the EKC hypothesis indicates that Lithuania can achieve short-term, medium-term, and long-term climate change mitigation and adoption goals and objectives approved by the Parliament of the Republic of Lithuania without deteriorating its economic growth.
\end{abstract}

Keywords: $\mathrm{CO}_{2}$ Emissions, Financial Development, EKC, Trade, Energy, FDI, and ARDL.

\section{Introduction}

Due to higher trustworthiness and confidence in financial markets, foreign investors started investing in the Lithuanian financial system, which in turn provided credit for economic development. ${ }^{1}$ These types of financial and economic developments are expected to attract foreign direct investment (FDI) and higher degrees of $\mathrm{R} \& \mathrm{D}$ investments (Hermes \& Lensink, 2003; Pineiro Chousa, Tamazian, \& Vadlamannati, 2017) which in turn speed up the economic growth (also see Tamazian et al., 2009: Frankel \& Romer, 1999), and henceforth affect the dynamics of the environmental performance. The recent Eurostat estimates of carbon emission indicate that

\footnotetext{
${ }^{1}$ The trustworthiness and confidence of financial market are scored 4.1 out of maximum 7.0 and ranked $65^{\text {th }}$ place out of 138 analyzed economies (TheBanks, 2018). Further, Lithuania has the highest country ceiling for deposits that can be assigned to local or foreign currency. Moody's country ceiling is "Aaa (prime)" for both local and foreign currency of Lithuania.

${ }^{2}$ The carbon emission has deteriorated in most EU member states including Portugal, Bulgaria, Ireland, Germany, the Netherland, and Croatia by 9.0 $\%, 8.1 \%, 6.8 \%, 5.4 \%, 4.6 \%$, and $4.3 \%$ respectively. However, the carbon emission has increased in eight EU member states including Latvia, Malta, Estonia, Luxembourg, Poland, Slovakia, Finland and Lithuania by
}

Lithuania is amongst the eight EU member states where carbon emission increased in $2018 .^{2}$

Understanding the impact of economic and financial development on the environmental conditions is becoming increasingly important since the ecological concerns are making their way into the key public policy agenda. We investigate these financial and economic developments of the Lithuanian economy in association with ecological sustainability. ${ }^{3}$ Financial and trade developments also accelerate economic growth through technological advancements (Birdsall \& Wheeler, 1993; Saint Akadiri, Lasisi, Uzuner, \& Akadiri, 2019). All these factors promoted the economic growth of the small economy like the Lithuanian economy (Balkevicius, 2013). Conversely, these economic activities cause the accumulation of

$8.5 \%, 6.7 \%, 4.5 \%, 3.7 \%, 3.5 \%, 2.4 \%, 1.9 \%$, and $0.6 \%$ respectively. These estimates are based on the Eurostat data. For further details on Lithuania, see Liobikiene, Mandravickaite, Krepstuliene, Bernatoniene, and Savickas, A. (2017).

${ }^{3}$ Ali, Abdul-Rahim, and Ribadu (2017), Salahuddin, Alam, Ozturk and Sohag (2017), Bekhet and Othman (2017), Zambrano-Monserrate, Carvajal-Lara, and Urgiles-Sanchez (2018), Charfeddine and Khediri (2016), Al-Mulali and Che Sab (2018), and Dogan and Turkekul (2016) provided the empirical evidences on this linkage between financial development and carbon dioxide. 
pollutant gases in the atmosphere leading to global warming (Andreoni and Galmarini, 2016) and drastic changes in the global climate (Nordhaus, 1977; Hanif, Raza, Gago-deSantos, \& Abbas, 2019). One of the dangerous and most emitted gases from economic activities is carbon dioxide $\left(\mathrm{CO}_{2}\right)$, which plays a crucial role in environmental degradation (Perez-Suarez \& Lopez-Menendez, 2015). In this trade-off, ecological sustainability is desired along with economic development-restricting environmental degradation throughout economic growth.

Given these reasons and concerns, the environmental Kuznets curve (EKC)-an inverted U-shaped relationship between economic growth and income inequality, initially proposed by Kuznets (1995)-has gained increasing popularity in academic and policy circle. ${ }^{4}$ The EKC elaborates on the relationship between the quality of the environment and the growth of an economy. More directly, this hypothesis explains that with the growth of an economy, environmental degradation increases to a certain point of income inequality, after that turning point, environmental degradation decreases (Grossman \& Krueger, 1995), concluding an inverted U-shaped curve. In this nexus, economic growth is both the problem and the solution for environmental degradation. Knowing this solution, many researchers investigated this issue for different countries and regions to tell whether economic growth can be a solution to environmental problems in that country or region (see Raggad, 2018; Bekhet \& Othman, 2018; Shahzad, Kumar, Zakaria, \& Hurr, 2017). Liobikiene, Mandravickaite, Krepstuliene, Bernatoniene, and Savickas (2017) reveal that none of the Baltic states, including Lithuania, has a clear policy framework for the greenhouse gases (GHG) emission reduction, even though GHG emission reduction is the critical priority in the Lithuanian Sustainable Development Strategy. Following this strategy, the Parliament of the Republic of Lithuania approved the policy at the national level in 2012 to manage the climate changes. For this purpose, policymakers have developed and implemented climate change management goals in short-term, mediumterm, and long-term. Lithuanian GDP per capita has increased by 153.61 percent over the last three decades, and the critical challenge for policymakers is to reduce carbon emissions. Now, policymakers need empirical evidence on the association between greenhouse gases emission and the economic variables. To the best of our knowledge, no one has analyzed the role of economic growth, financial development, trade, and FDI in the environmental Kuznets curve for the case of Lithuania. Due to the increasing trend of energy consumption, we also include energy in this investigation. Consequently, we aim to test whether the Environmental Kuznets Curve (EKC) relationship for economic growth and financial development holds or not.

The methods of research include the ARDL bounds and Granger causality. The rest of the paper is organized as follows. Section 2 discusses the related literature. Section 3 presents the data and methods for analysis. Section 4

\footnotetext{
${ }^{4}$ EKC is an extension of the Kuznets Curve (KC).

${ }^{5}$ For the similar evidences, see Bekhet and Othman (2018), Balaguer and Cantavella (2018), Sinha and Shahbaz (2018), Zhang (2018), Cai et al. (2018), Salahuddin el al. (2017), Shahzad et al. (2017), Bekhet and Othman (2017), Isik et al. (2017), Ali, Law, and Zannah (2016), Ali et al.
}

elaborates on the empirical results and analysis. This paper is concluded in the last section.

\section{Related Literature}

Different researchers investigate this emerging issue with different economic actors to capture the impact on the environment. Dogan and Turkekul (2016) analyze the effect of trade, energy, financial development, and urbanization on environmental degradation. Applying ARDL, they conclude that energy consumption and urbanization cause to increase environmental degradation, while trade improves the environment for the USA. Bekhet and Othman (2017) and Cai, Yin, and Varis (2018) provide similar empirical evidence for the case of Malaysia and China, respectively. Applying F-Bound and VECM, Bekhet and Othman (2017) offer the anecdotal evidence of an inverted $\mathrm{u}$-shaped relationship between $\mathrm{CO} 2$ emissions and urbanization in the long run.

Many studies analyze the role of EKC in the presence of energy. For instance, Bekhet and Othman (2018) utilize renewable energy and report the inverted N-shaped EKC for the case of Malaysia. Likewise, Sinha and Shahbaz (2018) also investigate this issue in the presence of energy generation and energy consumption for the instance of India. Applying ARDL, they conclude inverted U-shaped EKC and a negative relationship between renewable energy generation and carbon dioxide. Different researchers introduce variables like financial development, FDI, domestic investment, and population density in the EKC model.

Furthermore, Balaguer and Cantavella (2018) use education, income, and oil prices in the model and find out that income and education reduce the emissions level for the case of Australia. Zhang (2018) uses the trade and non-fossil fuel electricity consumption in the EKC model and concludes that greater use of non-fossil fuel electricity can solve the problem of environmental degradation for South Korea. Similarly, Isik, Kasimati, and Ongan (2017) analyze the impact of tourism expenditure on the environment and suggest controlling tourism expenditure as these expenditures have a strong negative effect on the environment. Bekhet and Othman (2017) incorporate domestic investment along with financial development, urbanization, and energy consumption. Applying F-Bounds and VECM, they report the inverted $\mathrm{u}$-shaped relationship between $\mathrm{CO} 2$ emissions and urbanization in the long run.

Given all that has been mentioned so far, an economy needs to know the validity or non-validity of the EKC hypothesis so that proper policies should be adopted to control environmental degradation. Existing literature is inconclusive since the EKC hypothesis does not hold for many countries and valid for others. For instance, Zambrano-Monserrate et al. (2018), Ahmad et al. (2017), and Charfeddine and Khediri (2016) find that EKC is valid for Singapore, Croatia, and UAE, respectively. ${ }^{5}$ Another strand of literature argues that the EKC hypothesis does not
(2017), and Dogan and Turkekul (2016). These studies apply ARDL ARDL bounds, ARDL with structural breaks, VECM Granger Causality, CUSUM, CUSUMSQ, DOLS, FOMLS, and Gregory and Hansen and Hatemi-J approaches. 
hold. For instance, Raggad (2018), Gill, Viswanathan, and Hassan (2018), Ali et al. (2017), Katircioglu and Katircioglu (2018), and Al-Mulali et al. (2018) confirms the non-validity of EKC hypothesis for Saudi Arabia, Malaysia, Pakistan, Turkey, and Kenya respectively. Recently, Khan, Teng, and Khan (2019) reveals that coal consumption, oil consumption, economic growth, and natural gas consumption have a positive impact on the environmental degradations in Pakistan both in the short-run and long-run. They further recommend that environmental degradation can be reduced by promoting renewable energy resources in Pakistan.

Working on similar lines, Khan, Teng, Khan, and Khan (2019) included the globalization in this interaction. Applying dynamic ARDL simulations model Jordan and Philips (2018) on the annual data from 1971 to 2016, their results indicate that energy consumption, financial development, trade, FDI, and globalization has a positive impact on the carbon emission in Pakistan. Conversely, their empirical investigation reveals that trade, innovation, and FDI hurts the carbon emission in the short-run. As far as Lithuania is concerned, we could not find any study on the EKC hypothesis from the existing literature on the topic. ${ }^{6}$ Returning to the economic and financial factors of Lithuania, we analyze the trends in the critical indicators, including (i) carbon dioxide emission; (ii) electric power consumption; (iii) domestic credit to private sector; (iv) trade; and (v) foreign direct investment. In terms of these indicators, Lithuania is one of the high-income economies out of the Baltic States that generates its income from machinery, food processing, electronics, and textile and furniture products. Since joining the European Union in 2004, Lithuania's real GDP growth rate is 1.2 percent above the European Union. Financial market development gained 59th position out of 138 stable financial markets with a score of 4.1 (Schwab, 2017). As was pointed out in the earlier section of this paper, financial and economic development affects environmental performance. Therefore, it is needed to investigate the EKC hypothesis for Lithuania to suggest relevant policies.

To fill this literature gap, the present study investigates the framework of the Environmental Kuznets Curve (EKC) hypothesis for Lithuania using the Autoregressive Distributed Lag Approach (ARDL). In addition to GDP, we also incorporate variables like financial development, trade openness, energy use, and foreign direct investment in the EKC framework for the analysis.

\section{Data and Methods for Analysis}

We apply the reduced-form model to analyze the existence of the EKC hypothesis in Lithuania since the reduced form allows us to investigate the direct and indirect association among the variables. We incorporate the variables of income, financial development, trade, energy use, and foreign direct investment to analyze the impact of these economic and financial indicators on environmental quality. In this framework, the basic model in functional form is given in Equation 1 as follows.

$$
C O_{2 t}=f\left(G D P_{t}, G D P_{t}^{2}, F D_{t}, F D_{t}^{2}, T R D_{t}, E U_{t}, F D I_{t}\right)(1)
$$

\footnotetext{
${ }^{6}$ This is according to the best information of the authors.
}

Equation 1 includes $\mathrm{CO}_{2}$ emissions $\left(\mathrm{CO}_{2}\right)$, gross domestic product (GDP), the square of gross domestic product $\left(\mathrm{GDP}^{2}\right)$, financial development $(\mathrm{FD})$, the square of financial development $\left(\mathrm{FD}^{2}\right)$, trade (TRD), energy use (EU) and foreign direct investment (FDI). Following Charfeddine and Khediri (2016), we extend this basic functional form to three different models with financial development and square of financial development. Model one (Equation 2) investigates the impact of income, financial development, and trade on the environment. Model two (Equation 3) incorporate the additional variable of energy use in the model one, and model three (Equation 4) extend the model two by incorporating FDI. Following the existing literature (Bekhet and Othman, 2017; Zambrano-Monserrate et al., 2018; Sinha and Shahbaz, 2018), we convert all variables into natural logarithm to obtain direct elasticity and consistent and reliable results. In this setting, all three EKC models are given in Equation 2 to 4 below.

Model I: EKC model with financial development and trade.

$\ln \mathrm{CO}_{2 t}=\gamma_{0}+\gamma_{1} \ln \mathrm{GDP}_{\mathrm{t}}+\gamma_{2} \ln \mathrm{GDP}_{\mathrm{t}}^{2}+\gamma_{3} \ln \mathrm{FD}_{\mathrm{t}}+$ $\gamma_{4} \ln \mathrm{FD}_{\mathrm{t}}^{2}+\gamma_{5} \ln \mathrm{TRD}_{\mathrm{t}}+\epsilon_{t}$

Model II: EKC model with financial development, trade, and energy use

$$
\ln C O_{2 t}=\gamma_{0}+\gamma_{1} \ln \mathrm{GDP}_{\mathrm{t}}+\gamma_{2} \ln \mathrm{GDP}_{\mathrm{t}}^{2}+\gamma_{3} \ln \mathrm{FD}_{\mathrm{t}}+
$$

$\gamma_{4} \ln \mathrm{FD}_{\mathrm{t}}^{2}+\gamma_{5} \ln \mathrm{TRD}_{\mathrm{t}}+\gamma_{6} \ln \mathrm{EU}_{\mathrm{t}}+\epsilon_{t}$

Model III: EKC model with financial development, trade, energy use, and FDI

$\ln \mathrm{CO}_{2 t}=\gamma_{0}+\gamma_{1} \ln \mathrm{GDP}_{\mathrm{t}}+\gamma_{2} \ln \mathrm{GDP}_{\mathrm{t}}^{2}+\gamma_{3} \ln \mathrm{FD}_{\mathrm{t}}+$ $\gamma_{4} \ln \mathrm{FD}_{\mathrm{t}}^{2}+\gamma_{5} \ln \mathrm{TRD}_{\mathrm{t}}+\gamma_{6} \ln \mathrm{EU}_{\mathrm{t}}+\gamma_{7} \ln \mathrm{FDI}_{\mathrm{t}}+\epsilon_{t}$

We collect the data on the above variables from the World Bank database on World Development Indicators (WDI) from 1989 to 2018 for Lithuania (World Bank, 2015). We obtain data on $\mathrm{CO}_{2}$ emissions in kilo tons, GDP per capita (constant 2010), domestic credit to private sector (per cent of GDP) which is used as proxy for financial development, trade (per cent of GDP), energy use (kg of oil equivalent per capita) and Foreign direct investment (per cent of GDP).

Considering the economic weakness of the EKC (Stern, 2004; Tamazian, Chousa, \& Vadlamannati, 2009), we apply Autoregressive Distributed Lag (ARDL) bounds testing procedure comparatively recently developed by Pesaran, Shin, and Smith (2001). ${ }^{7}$ The ARDL technique has a couple of advantages over other cointegration techniques, including Engle and Granger (1987) and Johansen and Juselius (1990). One of the significant benefits is that ARDL can be applied irrespective of their level of integration except I (2). Second, the ARDL procedure works better in the small sample as compared to the Johansen and Juselius cointegration technique (Pesaran \& Shin, 1998). Third, the ARDL bound testing approach provides valid t-statistics and unbiased long-run coefficients, even in the presence of endogenous regressors (Boutabba, 2014; Narayan, 2005). Fourth, ARDL incorporates enough lags to capture the data generating process in general to specific modeling framework as elaborated in Laurenceson and Chai (2003). Fifth, the error correction term (ECM) derived through ARDL integrates short-run adjustments with long-run

7 Also see Boutabba, M. A. (2014) for the further details on ARDL Bounds testing procedure. 
equilibrium without losing long-run information (Pesaran \& Shin, 1999; Boutabba, 2014). The ARDL bounds testing approach consists of two steps to estimate the long-run relationship. The first step is to determine cointegration through the Bound test. In the presence of cointegration, the second step is to estimate both long-run and short-run models.

To estimate the cointegration among the concerned variables, we convert our models 1-3 (Equation 2-4) into the ARDL 1-3 model (Equation No 5-7) as follows.

In this setting, we use the following Equation 5 to estimate ARDL-1.

$\Delta \ln C O_{2 t}=\gamma_{0}+\sum_{i=1}^{a} \gamma_{1 i} \Delta \ln C O_{2 t-i}+$

$\sum_{i=0}^{b} \gamma_{2 i} \Delta \ln G D P_{t-i}+\sum_{i=0}^{c} \gamma_{3 i} \Delta \ln G D P_{t-1}^{2}+$

$\sum_{i=0}^{d} \gamma_{4 i} \Delta \ln F D_{t-i}+\sum_{i=0}^{e} \gamma_{5 i} \Delta \ln F D_{t-1}^{2}+$

$\sum_{i=0}^{f} \gamma_{6 i} \Delta \ln T R D_{t-i}+\alpha_{1} \ln C O_{2 t-1}+\alpha_{2} \ln G D P_{t-1}+$

$\alpha_{3} \ln G D P_{t-1}^{2}+\alpha_{4} \ln F D_{t-1}+\alpha_{5} \ln F D_{t-1}^{2}+\alpha_{6} \ln T R D_{t-1}+$

$\epsilon_{t}$

We use the following Equation 6 to estimate ARDL-2.

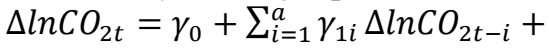

$\sum_{i=0}^{b} \gamma_{2 i} \Delta \ln G D P_{t-i}+\sum_{i=0}^{c} \gamma_{3 i} \Delta \ln G D P_{t-1}^{2}+$

$\sum_{i=0}^{d} \gamma_{4 i} \Delta \ln F D_{t-i}+\sum_{i=0}^{e} \gamma_{5 i} \Delta \ln F D_{t-1}^{2}+$

$\sum_{i=0}^{f} \gamma_{6 i} \Delta \ln T R D_{t-i}+\sum_{i=0}^{g} \gamma_{7 i} \Delta \ln E U_{t-i}+\alpha_{1} \ln C O_{2 t-1}+$ $\alpha_{2} \ln G D P_{t-1}+\alpha_{3} \ln G D P_{t-1}^{2}+\alpha_{4} \ln F D_{t-1}+\alpha_{5} \ln F D_{t-1}^{2}+$ $\alpha_{6} \ln T R D_{t-1}+\alpha_{7} \ln E U_{t-1}+\epsilon_{t}$

Similarly, we use the following Equation 7 to estimate ARDL-3.

$$
\Delta \ln C O_{2 t}=\gamma_{0}+\sum_{i=1}^{a} \gamma_{1 i} \Delta \ln C O_{2 t-i}+
$$

$\sum_{i=0}^{b} \gamma_{2 i} \Delta \ln G D P_{t-i}+\sum_{i=0}^{c} \gamma_{3 i} \Delta \ln G D P_{t-1}^{2}+$

$\sum_{i=0}^{d} \gamma_{4 i} \Delta \ln F D_{t-i}+\sum_{i=0}^{e} \gamma_{5 i} \Delta \ln F D_{t-1}^{2}+$

$\sum_{i=0}^{f} \gamma_{6 i} \Delta \ln T R D_{t-i}+\sum_{i=0}^{g} \gamma_{7 i} \Delta \ln E U_{t-i}+$

$\sum_{i=0}^{h} \gamma_{8 i} \Delta \ln F D I_{t-i}+\alpha_{1} \ln C O_{2 t-1}+\alpha_{2} \ln G D P_{t-1}+$ $\alpha_{3} \ln G D P_{t-1}^{2}+\alpha_{4} \ln F D_{t-1}+\alpha_{5} \ln F D_{t-1}^{2}+\alpha_{6} \ln T R D_{t-1}+$ $\alpha_{7} \ln E U_{t-1}+\alpha_{8} \ln F D I_{t-1}+\epsilon_{t}$

Where $\gamma$ and $\alpha$ represent short-run and long-run coefficients, respectively. Following Narayan (2005), we use Wald statistic for the significance of all variables in the cointegration test. And we use $F$-statistic to test the significance of the association. Comparing the value of $F$ statistic with critical values of upper and lower bound, cointegration exists if the value of $F$-statistic is above the upper bound. ${ }^{8}$

After the conclusion of the cointegration association, we estimate the long-run coefficients for models ARDL-1, ARDL-2, and ARDL-3 using Equation (8), Equation (9) and Equation (10) respectively.

$$
\ln C O_{2 t}=\gamma_{0}+\sum_{i=1}^{a} \gamma_{1 i} \ln C O_{2 t-i}+
$$

$\sum_{i=0}^{b} \gamma_{2 i} \ln G D P_{t-i}+\sum_{i=0}^{c} \gamma_{3 i} \ln G D P_{t-1}^{2}+$

$\sum_{i=0}^{d} \gamma_{4 i} \ln F D_{t-i}+\sum_{i=0}^{e} \gamma_{5 i} \ln F D_{t-1}^{2}+$

$\sum_{i=0}^{f} \gamma_{6 i} \ln T R D_{t-i}+\epsilon_{t}$

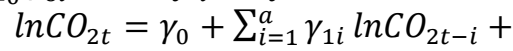

$\sum_{i=0}^{b} \gamma_{2 i} \ln G D P_{t-i}+\sum_{i=0}^{c} \gamma_{3 i} \ln G D P_{t-1}^{2}+$

$\sum_{i=0}^{d} \gamma_{4 i} \ln F D_{t-i}+\sum_{i=0}^{e} \gamma_{5 i} \ln F D_{t-1}^{2}+$

$\sum_{i=0}^{f} \gamma_{6 i} \ln T R D_{t-i}+\sum_{i=0}^{g} \gamma_{7 i} \ln E U_{t-i}+\epsilon_{t}$

$\operatorname{lnCO} O_{2 t}=\gamma_{0}+\sum_{i=1}^{a} \gamma_{1 i} \ln C O_{2 t-i}+$

$\sum_{i=0}^{b} \gamma_{2 i} \ln G D P_{t-i}+\sum_{i=0}^{c} \gamma_{3 i} \ln G D P_{t-1}^{2}+$

\footnotetext{
${ }^{8}$ In the case of multicollinearity, this problem can be overlooked (Nieh
} and $\mathrm{Ho}, 2006$ ) $\sum_{i=0}^{d} \gamma_{4 i} \ln F D_{t-i}+\sum_{i=0}^{e} \gamma_{5 i} \ln F D_{t-1}^{2}+$

$\sum_{i=0}^{f} \gamma_{6 i} \ln T R D_{t-i}+\sum_{i=0}^{g} \gamma_{7 i} \ln E U_{t-i}+$

$\sum_{i=0}^{h} \gamma_{8 i} \ln F D I_{t-i}+\epsilon_{t}$

In all three above equations, $\gamma_{2}>0$ and $\gamma_{3}<0$ indicate that income and $\mathrm{CO}_{2}$ emission relationship is invested U-shape, which is EKC. Conversely, $\gamma_{2}<0$ and $\gamma_{3}>0$ indicates that income and $\mathrm{CO}_{2}$ emission relationship is U-shaped. Similarly, $\gamma_{4}>0$ and $\gamma_{5}<0$ reveals that the inverted $\mathrm{U}$-shared relationship between financial development and $\mathrm{CO}_{2}$ emission. Nonetheless, $\gamma_{4}<0$ and $\gamma_{5}>0$ indicates the U-shaped relationship between income and $\mathrm{CO}_{2}$ emission.

After the estimation of long-run coefficients, we estimate the short-run coefficients for models ARDL-1, ARDL-2, and ARDL-3 using Equation (11), Equation (12) and Equation (13) respectively.

$\Delta \ln C O_{2 t}=\gamma_{0}+\sum_{i=1}^{a} \gamma_{1 i} \Delta \ln C O_{2 t-i}+$ $\sum_{i=0}^{b} \gamma_{2 i} \Delta \ln G D P_{t-i}+\sum_{i=0}^{c} \gamma_{3 i} \Delta \ln G D P_{t-1}^{2}+$

$\sum_{i=0}^{d} \gamma_{4 i} \Delta \ln F D_{t-i}+\sum_{i=0}^{e} \gamma_{5 i} \Delta \ln F D_{t-1}^{2}+$

$\sum_{i=0}^{f} \gamma_{6 i} \Delta \ln T R D_{t-i}+\emptyset c_{t-1}+\epsilon_{t}$

$\Delta \ln C O_{2 t}=\gamma_{0}+\sum_{i=1}^{a} \gamma_{1 i} \Delta \ln C O_{2 t-i}+$

$\sum_{i=0}^{b} \gamma_{2 i} \Delta \ln G D P_{t-i}+\sum_{i=0}^{c} \gamma_{3 i} \Delta \ln G D P_{t-1}^{2}+$

$\sum_{i=0}^{d} \gamma_{4 i} \Delta \ln F D_{t-i}+\sum_{i=0}^{e} \gamma_{5 i} \Delta \ln F D_{t-1}^{2}+$

$\sum_{i=0}^{f} \gamma_{6 i} \Delta \ln T R D_{t-i}+\sum_{i=0}^{g} \gamma_{7 i} \Delta \ln E U_{t-i}+\emptyset c_{t-1}+\epsilon_{t}$

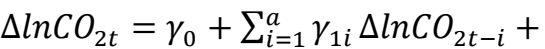
$\sum_{i=0}^{b} \gamma_{2 i} \Delta \ln G D P_{t-i}+\sum_{i=0}^{c} \gamma_{3 i} \Delta \ln G D P_{t-1}^{2}+$

$\sum_{i=0}^{d} \gamma_{4 i} \Delta \ln F D_{t-i}+\sum_{i=0}^{e} \gamma_{5 i} \Delta \ln F D_{t-1}^{2}+$

$\sum_{i=0}^{f} \gamma_{6 i} \Delta \ln T R D_{t-i}+\sum_{i=0}^{g} \gamma_{7 i} \Delta \ln E U_{t-i}+$

$\sum_{i=0}^{h} \gamma_{8 i} \Delta \ln F D I_{t-i}+\emptyset c_{t-1}+\epsilon_{t}$

In the above three Equations $(11,12,13)$, the correction term $c_{t-1}$ indicates the speed of adjustment back to long-run equilibrium after a short run shock (Jalil \& Feridun, 2011). In this framework, $\varnothing$ represents the coefficient of error correction in the lagged form, which is expected to have a significant negative value in all models. After the estimation of models, we perform four different kinds of diagnostic tests, including (i) serial correlation; (ii) functional form; (iii) normality; and (iv) heteroscedasticity. In the end, we apply the test of the cumulative sum (CUSUM) and test of cumulative sum squares (CUSUMQ) to check the stability of models.

\section{Empirical Results and Analysis}

We start our analysis with the investigation of unit roots, and after confirmation, we proceed to investigate the bounds cointegration in the series. We decide the short-run and long-run estimates, and then confirm the reliability of these estimates by applying different diagnostic tests. Finally, we perform the causality analysis to check the direction of causality among the variables of the study. For consistent and accurate results, the essential requirement for the ARDL bounds cointegration approach is to know the order of integration of all variables of the study, and that must be stationary at either I (0) or I (1). We apply unit root tests on $\mathrm{CO}_{2}$ emissions $\left(\mathrm{CO}_{2}\right)$, gross domestic product 
(GDP), financial development (FD), trade (TRD), energy use (EU), and foreign direct investment (FDI) for the confirmation of stationary in the data. In particular, we apply two unit-root tests, Augmented Dickey-Fuller (ADF) and Phillips-Perron tests, for the evidence of unit roots, and we report their results in Table 1.

Table 1

Analysis of Unit Roots

\begin{tabular}{|c|c|c|c|c|c|c|}
\hline Method & $\mathrm{CO}_{2}$ & GDP $\left(G^{2} P^{2}\right)$ & FD $\left(\mathrm{FD}^{2}\right)$ & TRD & $\mathbf{E U}$ & FDI \\
\hline ADF-Test & -1.09 & 0.90 & -1.37 & -0.47 & -2.14 & $-4.64 *$ \\
\hline$\Delta$ & $-4.80 *$ & $-3.16^{* *}$ & $-2.37 * *$ & $-5.17 *$ & $-4.89 *$ & \\
\hline PP-Test & $-4.99 *$ & 0.49 & -0.94 & -0.34 & -2.10 & $-4.59 *$ \\
\hline$\Delta$ & -- & $-2.99 * *$ & $-2.34 * *$ & $-5.82 *$ & $-6.78^{*}$ & -- \\
\hline Decision & I (1) & I (1) & I (1) & I (1) & I (1) & $\mathrm{I}(0)$ \\
\hline
\end{tabular}

Note: All variables used are in log form. $\Delta$ is the first difference term. ADF and PP refer Augmented Dickey-Fuller test Phillips-Perron test. The stationarity level for the square terms of GDP and FD is the same.*,** and *** denote the rejection of the null hypothesis at the one, five and ten per cent levels, respectively.

Both tests indicate that only foreign direct investment (FDI) is stationary at the level, while $\mathrm{CO}_{2}$, GDP, financial development (FD), trade (TRD), and energy use (EU) have unit roots at the level and become stationary after first difference. We draw this conclusion from Table 1, where all variables are integrated into I (1) except FDI which is integrated into I (0). After the confirmation of the order of integration of all variables, we extend this analysis to ARDL bounds cointegration. We report their results in Table 2 for all three ARDL models.

Table 2

Cointegration Test

\begin{tabular}{|c|c|c|c|}
\hline \multirow{2}{*}{ Estimated Model } & \multirow{2}{*}{ F-statistic } & \multicolumn{2}{|c|}{$5 \%$ critical values } \\
\hline & & I (0) & I (1) \\
\hline ARDL-1: $f\left(\mathrm{CO}_{2} / \mathrm{GDP}, \mathrm{GDP}^{2}, \mathrm{FD}, \mathrm{FD}^{2}, \mathrm{TRD}\right)$ & $5.40^{*}$ & 2.14 & 3.34 \\
\hline ARDL-2: $f\left(\mathrm{CO}_{2} / \mathrm{GDP}, \mathrm{GDP}^{2}, \mathrm{FD}, \mathrm{FD}^{2}, \mathrm{TRD}, \mathrm{EU}\right)$ & $10.91 *$ & 2.04 & 3.24 \\
\hline ARDL-3: $f\left(\mathrm{CO}_{2} / \mathrm{GDP}, \mathrm{GDP}^{2}, \mathrm{FD}, \mathrm{FD}^{2}, \mathrm{TRD}, \mathrm{EU}, \mathrm{FDI}\right)$ & $11.05^{*}$ & 1.97 & 3.18 \\
\hline
\end{tabular}

Note: *,**and $* * *$ denote the rejection of the null hypothesis at the one, five, and ten percent levels, respectively.

Table 2 presents the joint F-statistic values with upper and lower critical bounds values at 5 percent level of significance for each model. The $F$-statics values are higher than upper critical values $(3.34,3.24$, and 3.18) in all three models (Pesaran et al., 2001). ${ }^{9}$ Therefore, we have enough evidence to reject the null hypothesis, which postulates that all variables of the study are cointegrated and have long-run equilibrium relation. Further, the lagged error correction term $\Delta$ ct-1 also confirms the cointegration in the model (see Table 4). The value of $\Delta$ ct-1 $\left(\emptyset_{1}=-0.59, p<0.01\right)$ is negative and statistically significant at 1 percent level of significance, which confirms the long-run relationship among the variables (Banerjee et al., 1998; Kanjilal \& Ghosh, 2013).

Based on this cointegration evidence, we analyze longrun and short-run coefficients for ARDL-1, ARDL-2, and ARDL-3. We report the results of long-run and short-run estimates for GDP, GDP square $\left(\mathrm{GDP}^{2}\right)$, financial development $(\mathrm{FD})$, financial development square $\left(\mathrm{FD}^{2}\right)$, trade (TRD), energy use (EU) and foreign direct investment (FDI) in Table 3 and Table 4 respectively. The long-run estimates for ARDL-1 model reveal that coefficient of GDP $\left(\gamma_{2 b}=\right.$ $3.04, p<.01)$ is positive and significant at 1 percent level and the coefficient for a square of GDP $\left(\gamma_{3 c}=-0.21, p<\right.$ $.01)$ is negative and significant at 1 percent level of significance. Therefore, these results suggest that the coefficient of GDP is greater than zero, and the coefficient of
$\mathrm{GDP}^{2}$ is less than zero, which confirms the situation of the Environmental Kuznets Curve for Lithuania. These results reveal that the increase in the level of income will also increase environmental degradation at a certain level, then the increase in income decreases ecological degradation. These results are consistent with several other studies proving the EKC hypothesis for different countries (Farhani \& Ozturk, 2015; Zambrano-Monserrate et al., 2018; Ahmad et al., 2017; Charfeddine \& Khediri, 2016). Then, we extend our analysis to investigate the existence of an inverted U-shaped association between $\mathrm{CO}_{2}$ and financial development (FD). The coefficient of FD $\left(\gamma_{4 d 1}=-2.47, p<0.05\right)$ is negative and statistically significant at 5 percent level of significance, and $\mathrm{FD}^{2}\left(\gamma_{5 e 1}=0.39, p<0.05\right)$ is positive and statistically significant at 5 percent level of significance.

This non-validity of the EKC hypothesis of financial development reveals that an increase in financial development after a certain level causes environmental degradation, which postulates a U-shaped curve for $\mathrm{CO}_{2}$ emissions and financial development (See Jalil \& Feridun, 2011; Tamazian et al., 2009). Turning now to the gas emission, Table 3 indicates that the gas emission level increases with the increase in the level of trade (TRD) as the coefficient of TRD $\left.\gamma_{6 f 1}=0.66, p<0.05\right)$ is positive and statistically significant at 5 percent level of significance (Ali, Ashraf et al., 2017). The results of ARDL-2 and ARDL-3 models also confirms the findings as in ARDL-1, with additional variable of energy use (EU) and FDI in ARDL-2 and ARDL-3 respectively. In the ARDL-2 model, the EKC

\footnotetext{
${ }^{9}$ These critical values are given in Appendix in Narayan (2005).
} 
hypothesis for GDP is confirmed, but EKC for financial development (FD) is rejected. We also investigate the energy use (EU) in the same model, and the EU has a significant positive impact on the level of gas emissions $\left(\gamma_{7 g_{2}}=0.67\right.$, $p<0.01$ ). The positive and significant coefficient of energy use indicates that policymakers should make more efforts to develop energy-efficient technologies and use renewable energy sources to achieve growth (Cai et al., 2018).

In the ARDL-3 model, the results confirm the EKC hypothesis for the level of income. Further, we extend the analysis to investigate the role of FDI in environmental degradation. The coefficient of FDI $\left(\gamma_{8 h 3}=0.04, p>0.05\right)$ is statistically insignificant at 5 percent level of significance, which indicates the result is not meaningful economically. However, the coefficient is statistically significant at 10 percent level of significance, which is consistent with the Pollution Haven Hypothesis (PHH) — inward FDI worsens the environmental conditions (Salahuddin et al., 2017; Hoffmann et al., 2005).

Long-run Coefficients from the ARDL Models

\begin{tabular}{|c|c|c|c|}
\hline Regressors & ARDL-1 & ARDL-2 & ARDL-3 \\
\hline GDP & $3.04 *(0.27)$ & $1.67 *(0.20)$ & $1.28 *(0.27)$ \\
\hline $\mathrm{GDP}^{2}$ & $-0.21 *(0.01)$ & $-0.12 *(0.01)$ & $-0.10 *(0.02)$ \\
\hline FD & $-2.47 * *(1.15)$ & $-1.86 *(0.49)$ & $-1.04 *(0.25)$ \\
\hline $\mathrm{FD}^{2}$ & $0.39 * *(0.16)$ & $0.28 *(0.07)$ & $0.17 *(0.03)$ \\
\hline TRD & $0.66^{* *}(0.32)$ & $0.45 *(0.12)$ & $0.39 *(0.08)$ \\
\hline EU & & $0.67 *(0.10)$ & $0.76^{*}(0.14)$ \\
\hline FDI & & & $0.04 * * *(0.02)$ \\
\hline
\end{tabular}

Note: The dependent variable is $\mathrm{CO}_{2}$. The proper lag length of the estimated ARDL-1, ARDL-2, and ARDL-3 models are (1,1,1,1,0,0), (1,1,1,1,0,0,0), and $(1,1,1,0,0,0,0)$. We apply the AIC selection criterion for the lag length selection. The standard errors are given in parenthesis. *, ** and *** denote the rejection of the null hypothesis at the one, five, and ten per cent levels, respectively.

Short-run Coefficients and ECM from ARDL Models

Table 4

\begin{tabular}{|c|c|c|c|}
\hline Regressors & ARDL-1 & ARDL-2 & ARDL-3 \\
\hline$\Delta \mathrm{GDP}$ & $17.40 *(4.61)$ & $23.64 *(4.71)$ & $-16.16 *(-3.67)$ \\
\hline$\Delta \mathrm{GDP}^{2}$ & $-0.93 *(0.25)$ & $-1.27 *(0.25)$ & $0.85^{*}(3.43)$ \\
\hline$\Delta \mathrm{FD}$ & $-1.17 * *(0.54)$ & $-1.36 *(0.39)$ & $-0.84 *(-3.49)$ \\
\hline$\Delta \mathrm{FD}^{2}$ & $0.23 * *(0.09)$ & $0.23 *(0.07)$ & $0.13 *(3.79)$ \\
\hline$\Delta \mathrm{TRD}$ & $0.38 * *(0.17)$ & $0.37 *(0.11)$ & $0.31 *(7.15)$ \\
\hline$\Delta \mathrm{EU}$ & & $0.54 *(0.13)$ & $0.61 *(5.42)$ \\
\hline$\Delta \mathrm{FDI}$ & & & $0.03 * * *(1.81)$ \\
\hline $\mathrm{C}_{\mathrm{t}-\mathrm{i}}$ & $-0.59 *(0.09)$ & $-0.81 *(0.08)$ & $-0.80 *(0.07)$ \\
\hline
\end{tabular}

Note: The dependent variable is $\mathrm{CO}_{2}$. The proper lag length of the estimated ARDL-1, ARDL-2, and ARDL-3 models are (1,1,1,1,0,0), (1,1,1,1,0,0,0), and $(1,1,1,0,0,0,0)$. We apply the AIC selection criterion for the lag length selection. The standard errors are given in parenthesis. *, ** and *** denote the rejection of the null hypothesis at the one, five, and ten percent levels, respectively.

Then, we extend the analysis to investigate the short-run dynamics of this phenomenon. Table 4 presents the estimates for all ARDL models, and these results evident that coefficients of $\triangle \mathrm{GDP}, \triangle \mathrm{GDP}^{2}$ are positive and negative respectively, and both are statistically significant, confirming the EKC hypothesis for GDP in the short run. These results are consistent with the Balaguer and Cantavella (2018), Bekhet and Othman (2018), Cai et al. (2018), Sinha and Shahbaz (2018), Zhang (2018), Shahzad et al. (2017), Bekhet and Othman (2017), Isik et al. (2017), Ali, Law, and Zannah (2016), Ali et al. (2017), and Dogan and Turkekul (2016). Conversely, trade improves the environmental degradation in the short run. The lagged error correction term $c_{t-1}$ is negative and statistically significant in all models verifying the cointegration between the variables. ${ }^{10}$ Nonetheless, the magnitudes vary -0.59 to 0.81 . The coefficient of $c_{t-1}$ indicates the speed of adjustment back to long-run equilibrium after a short run shock. For instance, the coefficient of $c_{t-1}$ for ARDL 1 is -0.59 which implies that almost 59 percent of the disequilibrium in $\mathrm{CO}^{2}$ emission of the previous year's shock adjust back to the long run in the current year. Then, we apply five different diagnostic tests on all three models and present their results in Table 5. We apply Lagrange Multiplier, Ramsey's RESET, Skewness and Kurtosis, and ARCH tests for serial correlation, functional form, normality, and heteroscedasticity, respectively. In all tests, we have enough evidence to reject the null hypothesis confirming that the estimates in all three models are robust. Finally, we apply the stability test for goodness of fit of estimated parameters. For this purpose, we perform the cumulative sum (CUSUM) and the cumulative sum of the squares (CUSMQ) test. We report their results in Figure 1 and Figure 2. It is evident from both figures that plot for CUSM and CUSMQ test lie within the boundaries of 5 percent level of significance, confirming that all parameters are stable. After the cointegration analysis, we extend our analysis to the Granger causality. We apply this

${ }^{10}$ ARDL-1 $\left(\emptyset_{1}=-0.59, p<0.1\right) . A R D L-2\left(\emptyset_{2}=-0.81,, p<0.1\right)$. $A R D L-3\left(\emptyset_{3}=-0.80,, p<0.1\right)$. 
test for the variables of the interest, including $\mathrm{CO}_{2}, \mathrm{GDP}, \mathrm{FD}$, TRD, EU, and FDI, to find out the direction of causality among the concerned variables. We report the results of the pairwise Granger causality test in Table 6.

These results suggest that unidirectional causality runs from GDP to $\mathrm{CO}_{2}$ emissions, FD to GDP, FD to EU, FD to FDI, TRD to $\mathrm{CO}_{2}$ emissions, TRD to FD, and TRD to FDI.
The causality running from GDP to $\mathrm{CO} 2$ also confirms the existence of EKC (see Coondoo, \& Dinda, 2008; Akbostanc1, Turut-Asık, \& Tunc, 2009; Lee \& Lee, 2009). Overall, GDP has an impact on environmental degradation, and financial development has an impact on income, energy use, and foreign direct investment. Trade enhances the level of $\mathrm{CO}_{2}$ emissions, financial development, and foreign direct investment.

Table 5

Diagnostic Tests Results of the ARDL Models

\begin{tabular}{|c|c|c|c|}
\hline Statistics test & ARDL-1 & ARDL-2 & ARDL-3 \\
\hline Serial correlation & $0.44(0.51)$ & $0.93(0.24)$ & $0.56(0.41)$ \\
\hline Functional form & $0.80(0.38)$ & $0.00(0.99)$ & $1.19(0.29)$ \\
\hline Normality & $2.00(0.38)$ & $0.92(0.60)$ & $1.59(0.43)$ \\
\hline Heteroscedasticity & $0.64(0.79)$ & $0.48(0.74)$ & $0.61(0.78)$ \\
\hline
\end{tabular}

Note: The p-value for a diagnostic test is given in parentheses.

Results of Causality Test

\begin{tabular}{|c|c|c|c|c|c|c|}
\hline DV & $\Delta \mathrm{CO}_{2}$ & $\Delta$ GDP & $\Delta F D$ & $\Delta$ TRD & $\Delta \mathbf{E U}$ & $\Delta$ FDI \\
\hline$\Delta \mathrm{CO}_{2}$ & - & 3.20 & $9.68 *$ & 1.40 & 1.40 & 4.29 \\
\hline$\Delta \mathrm{GDP}$ & $11.55^{*}$ & - & 1.05 & 3.15 & 2.95 & $13.12 *$ \\
\hline$\Delta \mathrm{FD}$ & $10.90 *$ & 3.64 & - & 2.86 & 2.69 & 2.37 \\
\hline$\Delta \mathrm{TRD}$ & $6.74 * *$ & $6.57 * *$ & $6.15^{* *}$ & - & 3.72 & $12.12^{*}$ \\
\hline$\Delta \mathrm{EU}$ & 3.70 & 2.16 & $11.75^{*}$ & 1.49 & - & 3.99 \\
\hline$\Delta \mathrm{FDI}$ & $6.92 * *$ & 0.66 & 3.04 & 3.64 & 0.88 & - \\
\hline
\end{tabular}

Note: $* * *$ and $* * *$ denote the rejection of the null hypothesis at the one, five and ten percent levels, respectively. DV indicates dependent variables.

\section{Conclusion}

The main objective of this study is to test the existence of the Environmental Kuznets Curve (EKC) for Lithuania for 1971-2005. We examine the EKC hypothesis under the ARDL framework by using economic growth and financial development as indicators of environmental conditions. Our empirical analysis reveals the existence of a robust long-run relationship between carbon emission and economic growth, financial development, trade, energy consumption, and foreign direct investment. In particular, the positive sign with the economic growth and negative sing with its quadratic term reveals the existence of the EKC hypothesis. However, the negative sign with the financial development and positive sign with its quadratic term confirms the nonvalidity of the EKC hypothesis. The results of Granger's causality indicate that there is a unidirectional causality running from economic growth to carbon emission and financial development to carbon emission. We apply CUSUM and CUSUMSQ techniques on the error correction model, and the results of these techniques indicate that the estimated coefficients of the model are stable. The results of this empirical investigation also suggest that trade and energy consumption are significant determinants of $\mathrm{CO} 2$ emission in Lithuania. These results indicate that the policy makers in Lithuania should make such policies that encourage the investors to invest in green energy for the trade, financial, economic and ecological sustainability.

The significant evidence of the EKC relationship between $\mathrm{CO} 2$ emission and economic growth is encouraging. This evidence reveals that the implementation of the national strategy for climate change management policy is not hurting the economic growth at the current level of gross domestic product. Even though this analysis has provided useful insights, it must be noted that the development of the energy-efficient policies, primarily due to the non-validity of the EKC relationship between $\mathrm{CO} 2$ and financial development, needs to consider other variables than the underlying indicators in this study. Promising future research would be to consider the urbanization, the security of energy supply, and other environmental variables in the case of Lithuania.

\section{Annexure}

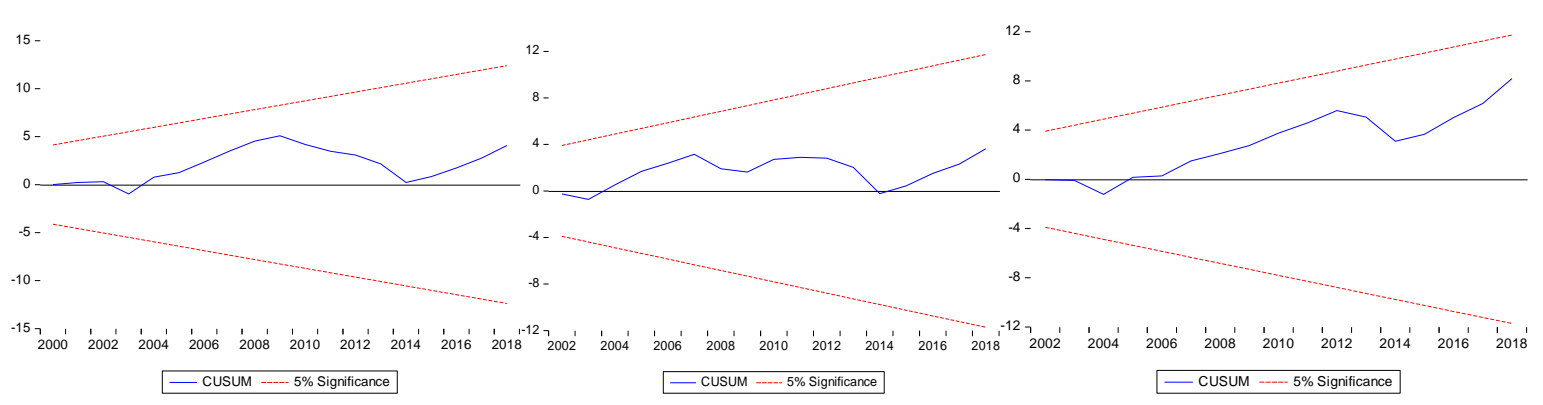

Figure 1. CUSUM Stability Test (ARDL-1, ARDL-2 and ARDL-3). 


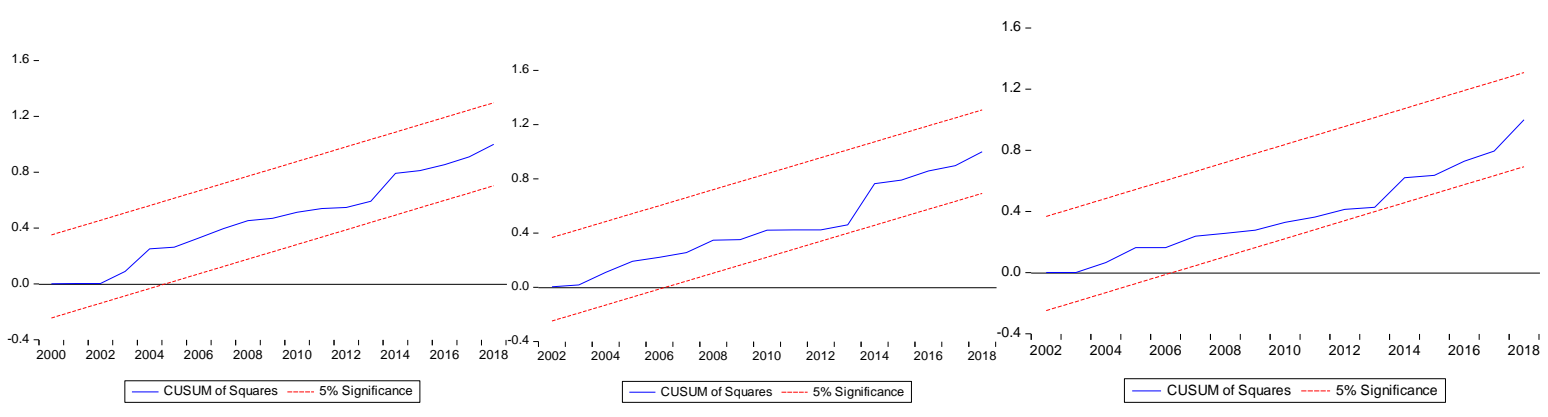

Figure 2. CUSUMQ Stability Test (ARDL-1, ARDL-2, and ARDL-3).

\section{References}

Ahmad, N., Du, L., Lu, J., Wang, J., Li, H. Z., \& Hashmi, M. Z. (2017). Modeling the CO2 emissions and economic growth in Croatia: Is there any environmental Kuznets curve? Energy, 123, 164-172. https://doi.org/10.10 16/j.energy.2016.12.106

Akbostanc1, E., Turut-Asık, S., \& Tunc, G. I. (2009). The relationship between income and environment in Turkey: is there an environmental Kuznets curve? Energy Policy, 37(3), 861-867. https://doi.org/10.1016/j.enpol.2008. 09.088

Ali, G., Ashraf, A., Bashir, M. K., \& Cui, S. (2017). Exploring the environmental Kuznets curve (EKC) in relation to the green revolution: a case study of Pakistan. Environmental Science \& Policy, 77, 166-171. https://doi.org/10. 1016/j.envsci.2017.08.019

Ali, H. S., Abdul-Rahim, A. S., \& Ribadu, M. B. (2017). Urbanization and carbon dioxide emissions in Singapore: evidence from the ARDL approach. Environmental Science and Pollution Research, 24(2), 1967-1974. https://doi.org/10.1007/s11356-016-7935-z

Ali, H. S., Law, S. H., \& Zannah, T. I. (2016). Dynamic impact of urbanization, economic growth, energy consumption, and trade openness on CO2 emissions in Nigeria. Environmental Science and Pollution Research, 23(12), 1243512443. https://doi.org/10.1007/s11356-016-6437-3

Al-mulali, U., \& Che Sab, C. N. B. (2018). Energy consumption, CO2 emissions, and development in the UAE. Energy Sources, Part B: Economics, Planning, and Policy, 13(4), 231-236. https://doi.org/10.1080/15567249.2012. 689796

Andreoni, V., \& Galmarini, S. (2016). Drivers in CO2 emissions variation: A decomposition analysis for 33 world countries. Energy, 103, 27-37. https://doi.org/10.1016/j.energy.2016.02.096

Balaguer, J., \& Cantavella, M. (2018). The role of education in the Environmental Kuznets Curve. Evidence from Australian data. Energy Economics, 70, 289-296. https://doi.org/10.1016/j.eneco.2018.01.021

Balkevicius, A. (2013). Lithuanian financial system transformation in the context of globalization. Trends Economics and Management, 7(14), 9-16. Retrieved from https://trends.fbm.vutbr.cz/index.php/trends/article/view/277/237

Banerjee, A., Dolado, J., \& Mestre, R. (1998). Error-correction mechanism tests for cointegration in a single-equation framework. Journal of time series analysis, 19(3), 267-283.https://doi.org/10.1111/1467-9892.00091

Bekhet, H. A., \& Othman, N. S. (2017). Impact of urbanization growth on Malaysia CO2 emissions: Evidence from the dynamic relationship. Journal of cleaner production, 154, 374-388. https://doi.org/10.1016/j.jclepro.2017.03.174

Bekhet, H. A., \& Othman, N. S. (2018). The role of renewable energy to validate dynamic interaction between CO2 emissions and GDP toward sustainable development in Malaysia. Energy Economics, 72, 47-61. https://doi.org/10.1016/j.eneco.2018.03.028

Birdsall, N., \& Wheeler, D. (1993). Trade policy and industrial pollution in Latin America: where are the pollution havens? The Journal of Environment \& Development, 2(1), 137-149. https://doi.org/10.1177\%2F107049 659300200107

Boutabba, M. A. (2014). The impact of financial development, income, energy, and trade on carbon emissions: Evidence from the Indian economy. Economic Modelling, 40, 33-41. https://doi.org/10.1016/j.econmod.2014.03.005

Cai, J., Yin, H., \& Varis, O. (2018). Impacts of urbanization on water use and energy-related CO2 emissions of residential consumption in China: A Spatio-temporal analysis during 2003-2012. Journal of Cleaner Production, 194, 23-33. https://doi.org/10.1016/j.jclepro.2018.05.117

Cai, Y., Sam, C. Y., \& Chang, T. (2018). Nexus between clean energy consumption, economic growth, and CO2 emissions. Journal of cleaner production, 182, 1001-1011. https://doi.org/10.1016/j.jclepro.2018.02.035 
Charfeddine, L., \& Khediri, K. B. (2016). Financial development and environmental quality in UAE: Cointegration with structural breaks. Renewable and Sustainable Energy Reviews, 55, 1322-1335. https://doi.org/10.10 16/j.rser. 2015.07.059

Coondoo, D., \& Dinda, S. (2008). Carbon dioxide emission and income: A temporal analysis of cross-country distributional patterns. Ecological Economics, 65(2), 375-385. https://doi.org/10.1016/j.ecolecon.2007.07.001

Dogan, E., \& Turkekul, B. (2016). CO2 emissions, real output, energy consumption, trade, urbanization, and financial development: testing the EKC hypothesis for the USA. Environmental Science and Pollution Research, 23(2), 1203-1213. https://doi.org/10.1007/s11356-015-5323-8

Engle, R. F., Granger, C. W. J., 1987. Cointegration and error correction representation: estimation and testing. Econometrica, 55, 251-276. https://doi.org/10.2307/1913236

Farhani, S., \& Ozturk, I. (2015). The causal relationship between CO2 emissions, real GDP, energy consumption, financial development, trade openness, and urbanization in Tunisia. Environmental Science and Pollution Research, 22(20), 15663-15676. https://doi.org/10.1007/s11356-015-4767-1

Frankel, J. A., \& Romer, D. H. (1999). Does trade cause growth? American economic review, 89(3), 379-399. https://doi.org/10.1257/aer.89.3.379

Gill, A. R., Viswanathan, K. K., \& Hassan, S. (2018). A test of the environmental Kuznets curve (EKC) for carbon emission and potential of renewable energy to reduce greenhouse gases (GHG) in Malaysia. Environment, Development, and Sustainability, 20(3), 1103-1114. https://doi.org/10.1007/s10668-017-9929-5

Grossman, G. M., \& Krueger, A. B. (1995). Economic growth and the environment. The quarterly journal of economics, 110(2), 353-377. https://doi.org/10.2307/2118443

Hanif, I., Raza, S. M. F., Gago-de-Santos, P., \& Abbas, Q. (2019). Fossil fuels, foreign direct investment, and economic growth have triggered CO2 emissions in emerging Asian economies: some empirical evidence. Energy, 171, 493501. https://doi.org/10.1016/j.energy.2019.01.011

Hermes, N., \& Lensink, R. (2003). Foreign direct investment, financial development, and economic growth. The Journal of Development Studies, 40(1), 142-163. https://doi.org/10.1080/00220380412331293707

Hoffmann, R., Lee, C. G., Ramasamy, B., \& Yeung, M. (2005). FDI and pollution: a granger causality test using panel data. Journal of International Development: The Journal of the Development Studies Association, 17(3), 311-317. https://doi.org/10.1002/jid.1196

Isik, C., Kasimat1, E., \& Ongan, S. (2017). Analysing the causalities between economic growth, financial development, international trade, tourism expenditure and/on the $\mathrm{CO} 2$ emissions in Greece. Energy Sources, Part B: Economics, Planning, and Policy, 12(7), 665-673. https://doi.org/10.1080/15567249.2016.1263251

Jalil, A., \& Feridun, M. (2011). The impact of growth, energy, and financial development on the environment in China: a cointegration analysis. Energy Economics, 33(2), 284-291. https://doi.org/10.1016/j.eneco.2010.10.003

Johansen, S., \& Juselius, K. (1990). Maximum likelihood estimation and inference on cointegration-with applications to the demand for money. Oxford Bulletin of Economics and Statistics, 52(2), 169-210. https://doi.org/10.1111/j. 1468-0084.1990.mp52002003.x

Jordan, S., \& Philips, A. Q. (2018). DYNARDL: Stata module to dynamically simulate autoregressive distributed lag (ARDL) models.

Kanjilal, K., \& Ghosh, S. (2013). Environmental Kuznets curve for India: Evidence from tests for cointegration with unknown structural breaks. Energy Policy, 56, 509-515. https://doi.org/10.1016/j.enpol.2013.01.015

Katircioglu, S., \& Katircioglu, S. (2018). Testing the role of urban development in the conventional environmental Kuznets curve: evidence from Turkey. Applied Economics Letters, 25(11), 741-746. https://doi.org/10.1080/ 13504851.2017.1361004

Khan, M. K., Teng, J. Z., \& Khan, M. I. (2019). Effect of energy consumption and economic growth on carbon dioxide emissions in Pakistan with a dynamic ARDL simulations approach. Environmental Science and Pollution Research, 1-11. https://doi.org/10.1007/s11356-019-05640-x

Khan, M. K., Teng, J. Z., Khan, M. I., \& Khan, M. O. (2019). Impact of globalization, economic factors, and energy consumption on CO2 emissions in Pakistan. Science of the total environment, 688, 424-436. https://doi.org/10. 1016/j.scitotenv.2019.06.065

Kuznets, S. (1955). Economic growth and income inequality. The American economic review, 45(1), 1-28. https://www.jstor.org/stable/1811581

Laurenceson, J., \& Chai, J. C. (2003). Financial reform and economic development in China. Edward Elgar Publishing. https://doi.org/10.4337/9781843767190 
Habib-ur-Rahman, Ahmad Ghazali, Ghulam Ali Bhatti, Safdar Ullah Khan. Role of Economic Growth, Financial ...

Lee, C. C., \& Lee, J. D. (2009). Income and CO2 emissions: evidence from panel unit root and cointegration tests. Energy Policy, 37(2), 413-423. https://doi.org/10.1016/j.enpol.2008.09.053

Liobikiene, G., Mandravickaite, J., Krepstuliene, D., Bernatoniene, J., \& Savickas, A. (2017). Lithuanian achievements in terms of $\mathrm{CO} 2$ emissions based on the production side in the context of the EU-27. Technological and Economic Development of Economy, 23(3), 483-503. https://doi.org/10.3846/20294913.2015.1056278

Narayan, P. K. (2005). The saving and investment nexus for China: evidence from cointegration tests. Applied Economics, 37(17), 1979-1990. https://doi.org/10.1080/00036840500278103

Nieh, C. C., \& Ho, T. W. (2006). Does the expansionary government spending crowd out private consumption? Cointegration analysis in panel data. The Quarterly Review of Economics and Finance, 46(1), $133-148$. https://doi.org/10.1016/j.qref.2004.11.004

Nordhaus, W. D. (1977). Economic growth and climate: the carbon dioxide problem. The American Economic Review, 67(1), 341-346. https://www.jstor.org/stable/1815926

Perez-Suarez, R., \& Lopez-Menendez, A. J. (2015). Growing green? Forecasting CO2 emissions with environmental Kuznets curves and logistic growth models. Environmental Science \& Policy, 54, 428-437. https://doi.org/10. 1016/j.envsci.2015.07.015

Pesaran, M. H., \& Shin, Y. (1998). An autoregressive distributed lag modeling approach to cointegration analysis. Econometric Society Monographs, 31, 371-413.

Pesaran, M. H., Shin, Y., \& Smith, R. J. (2001). Bounds testing approaches to the analysis of level relationships. Journal of applied econometrics, 16(3), 289-326. https://doi.org/10.1002/jae.616

Pineiro Chousa, J., Tamazian, A., \& Vadlamannati, K. C. (2017). Does Higher Economic and Financial Development Lead to Environmental Degradation: Evidence from BRIC Countries. Energy Policy, 37(1), 2009. https://doi.org/10.1016/j.enpol.2008.08.025

Raggad, B. (2018). Carbon dioxide emissions, economic growth, energy use, and urbanization in Saudi Arabia: evidence from the ARDL approach and impulse saturation break tests. Environmental Science and Pollution Research, 117. https://doi.org/10.1007/s11356-018-1698-7

Rasoulinezhad, E., \& Saboori, B. (2018). Panel estimation for renewable and non-renewable energy consumption, economic growth, $\mathrm{CO} 2$ emissions, the composite trade intensity, and financial openness of the commonwealth of independent states. Environmental Science and Pollution Research, 1-17. Environmental Science and Pollution Research (2018) 25:17354-17370 https://doi.org/10.1007/s11356-018-1827-3

Saint Akadiri, S., Lasisi, T. T., Uzuner, G., \& Akadiri, A. C. (2019). Examining the impact of globalization in the environmental Kuznets curve hypothesis: the case of tourist destination states. Environmental Science and Pollution Research, 26(12), 12605-12615. https://doi.org/10.1007/s11356-019-04722-0

Salahuddin, M., Alam, K., Ozturk, I., \& Sohag, K. (2017). The effects of electricity consumption, economic growth, financial development, and foreign direct investment on $\mathrm{CO} 2$ emissions in Kuwait. Renewable and Sustainable Energy Reviews. (81), 2002-2010. https://doi.org/10.1016/j.rser.2017.06.009

Salahuddin, M., Alam, K., Ozturk, I., \& Sohag, K. (2018). The effects of electricity consumption, economic growth, financial development, and foreign direct investment on $\mathrm{CO} 2$ emissions in Kuwait. Renewable and Sustainable Energy Reviews, 81, 2002-2010. https://doi.org/10.1016/j.rser.2017.06.009

Schwab, K. (2017). The global competitiveness report 2017-2018. Geneva: World Economic Forum. Retrieved from http://www3.weforum.org/docs/GCR2017-

2018/05FullReport/TheGlobalCompetitivenessReport2017\%E2\%80\%932018.pdf

Shahzad, S. J. H., Kumar, R. R., Zakaria, M., \& Hurr, M. (2017). Carbon emission, energy consumption, trade openness, and financial development in Pakistan: A revisit. Renewable and Sustainable Energy Reviews, 70, $185-192$. https://doi.org/10.1016/j.rser.2016.11.042

Sinha, A., \& Shahbaz, M. (2018). Estimation of Environmental Kuznets Curve for CO2 emission: Role of renewable energy generation in India. Renewable Energy, 119, 703-711. https://doi.org/10.1016/j.renene.2017.12.058

Stern, D. I. (2004). The rise and fall of the environmental Kuznets curve. World Development, 32(8), 1419-1439. https://doi.org/10.1016/j.worlddev.2004.03.004

Tamazian, A., Chousa, J. P., \& Vadlamannati, K. C. (2009). Does higher economic and financial development lead to environmental degradation: evidence from BRIC countries. Energy Policy, 37(1), 246-253. https://doi.org/10. 1016/j.enpol.2008.08.025

TheBanks, e. (2018). Lithuania (Banking Sector). Retrieved from https://thebanks.eu/countries/Lithuania/banking_ sector

World Bank. (2015). World Bank data. World Bank. Retrieved from https://data.worldbank.org/ 
Zambrano-Monserrate, M. A., Carvajal-Lara, C., \& Urgiles-Sanchez, R. (2018). Is there an inverted U-shaped curve? The empirical analysis of the Environmental Kuznets Curve in Singapore. Asia-Pacific Journal of Accounting \& Economics, 25(1/2), 145-162. https://doi.org/10.1080/16081625.2016.1245625

Zhang, S. (2018). Is trade openness good for the environment in South Korea? The role of non-fossil electricity consumption. Environmental Science and Pollution Research, 1-13. https://doi.org/10.1007/s11356-018-1264-3

Zhu, H., Xia, H., Guo, Y., \& Peng, C. (2018). The heterogeneous effects of urbanization and income inequality on CO2 emissions in BRICS economies: evidence from panel quantile regression. Environmental Science and Pollution Research, 1-18. https://doi.org/10.1007/s11356-018-1900-y

The article has been reviewed.

Received in November 2018; accepted in February 2020. 